\title{
PELECEHAN SEKSUAL TERHADAP ANAK
}

\author{
Oleh : \\ Ratna Sari, Soni Akhmad Nulhaqim, \& Maulana Irfan
}

Email:

ratnaasariii@yahoo.com; soninulhaqim@yahoo.com; m sangirfan@gmail.com

\begin{abstract}
Abstrak:Anak adalah investasi dan harapan masa depan bangsa serta sebagai penerus generasi di masa mendatang. Dalam siklus kehidupan, masa anak-anak merupakan fase dimana anak mengalami tumbuh kembang yang menentukan masa depannya.Perlu adanya optimalisasi perkembangan anak, karena selain krusial juga pada masa itu anak membutuhkan perhatian dan kasih sayang dari orang tua atau keluarga sehingga secara mendasar hak dan kebutuhan anak dapat terpenuhi secara baik. Anak seharusnya dapat tumbuh dan berkembang menjadi manusia yang sehat jasmani dan rohani, cerdas, bahagia, bermoral tinggi dan terpuji, karena di masa depan mereka merupakan aset yang akan menentukan kualitas peradaban bangsa.
\end{abstract}

Kata kunci:anak, hak anak, kebutuhan dasar anak.

\section{Pendahuluan}

Anak seharusnya mendapatkan haknya dan salah satunya adalah mendapatkan perlindungan dari berbagai pihak, jika anak sudah berada di lingkungan sekolah, berarti anak harus mendapatkan perlindungan dari pihak sekolah.Jika anak sudah berada di lingkungan keluarganya, peran dan fungsi dari keluarga harus berjalan dengan semestinya. Selain itu, sudah ada pula undang-undang yang mengatur tentang hak anak yaitu, UU RI No. 23 Tahun 2002 tentang perlindungan anak pasal 1 (2) menyatakan bahwa "Perlindungan anak adalah segala kegiatan untuk menjamin dan melindungi anak dan hak-haknya agar dapat hidup, tumbuh, berkembang, dan berpartisipasi, secara optimal, sesuai dengan harkat dan martabat kemanusiaan, serta mendapat perlindungan dari kekerasan dan diskriminasi". Melihat UU tentang perlindungan anak tersebut, seharusnya setiap anak mendapatkan hak yang sama.

Sejalan dengan meningkatnya urgensi perlindungan anak di Indonesia maka, pemerintah1 Indonesia telah menyatakan komitmennya terhadap deklarasi AWorld Fit for Children (WFC) dalam 27 th United Nations General Assembly Special Session on Children pada tahun 2001.Diharapkan pemerintah dapat melakukan penanganan atas kasus terkait anak dengan lebih baik.

Dengan demikian Indonesia diharapkanmenyusun suatu program nasional bagianak. Terdapat 4 bidang pokok yang mendapat perhatian khusus dalam deklarasi WFC yaitu promosi hidup sehat (promoting healthy lives), penyediaan pendidikan yang berkualitas (providingquality education), perlindungan terhadap perlakuan salah (abuse), eksploitasi dan kekerasan (protecting against abuse, exploitationand violence) dan penanggulangan HIV/AIDS (Ira Paramnastri dalam Jurnal Psikologi Early Prevention Toward Sexual Abuse on Children, 2010).

Namun pada kenyataannya masih banyak anak yang tidak mendapatkan hak nya.Hal ini dibuktikan dengan adanya kasus pelecehan seksual pada anak yang terjadi di Jakarta International School (JIS).Jika melihat kasus tersebut, kita berpikir dimana saat itu pihak yang seharusnya 
melindungi anak.Hal tersebut sangat memprihatinkan, terlebih korbannya adalah anak-anak.Dari kasus ini dapat terlihat bahwa anak belum mendapatkan hak untuk mendapatkan perlindungan secara maksimal.Dan jika dilihat latar belakang sekolahnya, JIS adalah salah satu sekolah yang bertaraf internasional dan banyak masyarakat atau orangtua yang mempercayai anak-anaknya untuk dititipkan atau bersekolah di sekolah tersebut dengan berbagai alasan,salah satunya mungkin karena keamanan yang terjamin.Namun pada kenyataannya anak mereka menjadi korban tindakan pelecehan seksual, dan yang lebih membuat mirisnya lagi, hal tersebut dilakukan oleh pihak yang berada didalam sekolah tersebut.

\section{Pembahasan}

Kekerasan seksual salah satu kekerasan fisik yang termasuk tindakan krimal. Pelaku tindak kekerasan seksual melakukan untuk memuaskan hasratnya secara paksa. Tindakan kekerasan seksual tidak hanya berupa tindakan hubungan seksual secara paksa, namun aktivitas lain seperti meraba, bahkan jika hanya memandangi, hal ini sesuai dengan penuturan Orange dan Brodwin dalam Jurnal Psikologi Early Prevention Toward Sexual Abuse on Children yang menjelaskan bahwa kekerasan seksual pada anak adalah pemaksaan, ancaman atau keterperdayaan seorang anak dalam aktivitas seksual. Aktivitas seksual tersebut meliputi melihat, meraba, penetrasi (tekanan), pencabulandan pemerkosaan.Dampak kekerasan seksual pada anak dapat berupa fisik, psikologis, maupun sosial.Dampak secara fisik dapat berupa luka atau robek pada selaput dara.Dampak psikologi meliputi trauma mental, ketakutan, malu, kecemasan bahkan keinginan atau percobaan bunuh diri. Dampak sosial misalnya perlakuan sinis dari masyarakat di sekelilingnya, ketakutan terlibat dalam pergaulan dan sebagainya .

Kekerasan seksual pada anak mendapatkan perhatian dari banyak masyarakat karena kekerasan seksual pada anak merupakan tingkat kekerasan paling tinggi dibandingkan dengan kekerasan fisik dan psikologis.Diperkuat dengan data dari Komisi Nasional Perlindungan Anak yang menyatakan bahwa kekerasan seksual pada anak merupakan tingkat kekerasan yang paling tinggi dibandingkan dengan kekerasan fisik dan psikologis. Kekerasan pada anak di Indonesia sampai dengan September 2006 telah terjadi 861 kasus, 60\% diantaranya adalah kasus kekerasan seksual pada anak. Indonesia disorot sebagai negara yang memiliki perlindungan yang sangat lemah terhadap anak.

Kekerasan seksual pada anak tidak memandang korbannya anak laki-laki ataupun anak perempuan.Hal ini diperkuat oleh data yang terdapat pada Jurnal Gail Hornor 2010 bahwa anak perempuan dan laki-laki memungkinkan menjadi korban kekerasan seksual. Anak perempuan maupun laki-laki korban kekerasan seksual mengalami sejumlah masalah yang sama antara lain trauma fisik dan psikologis yang berkepanjangan, kehilangan semangat hidup, membenci lawan jenis dan memiliki keinginan untuk balas dendam (Dube et al., 2005 dalam Gail Hornor, Child Sexual Abuse: Consequences and Implication, 2010).

Kita sering sekali mendengar kasus yang melibatkan anak-anak, diantaranya adalah pelecehan seksual pada anak.Banyak sekali berita-berita di tv dihebohkan oleh kasus pelecehan seksual pada anak yang terjadi di salah satu sekolah bertaraf Internasional di Jakarta, yaitu Jakarta International School (JIS).

Dengan adanya kejadian ini membuat para orangtua khawatir dengan keberadaan anak-anaknya yang bersekolah di Jakarta International School (JIS).Dengan adanya kejadian ini para orangtua harus lebih memperhatikan anak-anaknya.Selain itu, dari pihak sekolah pun lebih meningkatkan keamanan untuk kepentingan anak didiknya.

Kasus pelecehan seksual dengan korban murid JIS ini menggemparkan Indonesia.Warga secara dekat mengikuti perkembangan kasus ini melalui media.Kasusnya sendiri sangat pelik yang terus mengalami perubahan dalam beberapa bulan terakhir.Semuanya berawal pada bulan maret 
ketika kasus pelecehan seksual terhadap murid muncul di JIS.Seorang murid di TK diyakini diperkosa beramai-ramai oleh beberapa petugas kebersihan.

Kemudian pada juni muncul kasus kedua ketika orangtua murid mengklaim bahwa anak mereka menjadi korban pelecehan seksual. Kasus kedua inilah yang menjerat neil dan ferdi (pelaku pelecehan seksual), dua guru JIS. Kasus ini untuk pertama kalinya menyeret guru atau staf pengajar disekolah tersebut. Tidak lama kemudian ibu korban dari kasus pertama juga menyatakan bahwa neil dan ferdi melakukan pelecehan seksual terhadap anaknya. Dari situ kasus ini pun berkembang

\section{Tanda terjadi pelecehan seksual}

Patricia A Moran dalam buku Slayer of the Soul, 1991, mengatakan, menurut riset, korban pelecehan seksual adalah anak laki-laki dan perempuan berusia bayi sampai usia 18 tahun. Kebanyakan pelakunya adalah orang yang mereka kenal dan percaya.Gejala seorang anak yang mengalami pelecehan seksual tidak selalu jelas. Ada anak-anak yang menyimpan rahasia pelecehan seksual yang dialaminya dengan bersikap manis dan patuh, berusaha agar tidak menjadi pusat perhatian. Meskipun pelecehan seksual terhadap anak tidak memperlihatkan bukti mutlak, tetapi jika tanda-tanda di bawah ini tampak pada anak dan terlihat terus-menerus dalam jangka waktu panjang, kiranya perlu segera mempertimbangkan kemungkinan anak telah mengalami pelecehan seksual. Tanda dan indikasi ini diambil Jeanne Wess dari buku yang sama: balita tanda-tanda fisik, antara lain memar pada alat kelamin atau mulut, iritasi kencing, penyakit kelamin, dan sakit kerongkongan tanpa penyebab jelas bisa merupakan indikasi seks oral.

Tanda perilaku emosional dan sosial, antara lain sangat takut kepada siapa saja atau pada tempat tertentu atau orang tertentu, perubahan tingkah laku yang tiba-tiba, gangguan tidur (susah tidur, mimpi buruk, dsb), menarik diri atau depresi, serta perkembangan terhambat. Anak usia prasekolah gejalanya sama ditambah tanda-tanda berikut:

- Tanda fisik: antara lain perilaku regresif, seperti mengisap jempol, hiperaktif, keluhan somatik seperti sakit kepala yang terus-menerus, sakit perut, sembelit.

- Tanda pada perilaku emosional dan sosial: kelakuan yang tiba-tiba berubah, anak mengeluh sakit karena perlakuan seksual.

Dampak yang akan ditimbulkan dari adanya pelecehan seksual pada anak diantaranya,

- Dampak fisik: Memar dan luka atau infeksi pada bagian tertentu

- Dampak emosi: Merasa terancam, tertekan, gelisah dan cemas.

Orangtua diharapkan:

- Konsultasi pada psikologi untuk latihan mengelola emosi, dan mempelajarai perkembangan anak.

- Ajak anak ke dokter untuk memeriksakan kondisi fisik.

- Pahami perkembangan anak. Di usia 5 hingga 8 tahun, anak sedang berada pada tahap ingin menunjukkan kemampuan, mereka ingin berekreasi. Tidak semua tindakan anak merupakan kenakalan, mereka tidak tahu bahwa tingkah lakunya salah atau kurang tepat.

Bantuan untuk anak:

- Pemeriksaan psikologis oleh psikolog untuk mengetahui gangguan emosi yang dialaminya dan mendapat terapi yang sesuai.

- Tumbuhkan kembali rasa percaya diri anak. Terimalah apa yang mereka lakukan dengan tidak lupa memberitahu tindakan apa yang seharusnya dilakukan.

- Bila orang tua bukan pelaku kekerasan, yakinkan anak bahwa ia sangat dicintai.

Menurut Hurlock, Elisabeth. 1980, Psikologi Perkembangan .Jakarta : Erlangga. anak yang mengalami pelecehan seksual akan mengalami gangguan secara psikologisnya, anak yang mengalami 
pelecehan seksual akan mengalami trauma yang mendalam. jika hal tersebut terjadi, maka akan mempengaruhi tumbuh kembang si anak. pada buku Elisabeth Hurlock membagi tugas perkembangan menjadi 2 bagian, yaitu tugas perkembangan periode anak awal dan tugas perkembangan periode anak akhir.

- tugas perkembangan periode anak awal

1. penyempurnaan pemahaman tentang konsep-konsep sosial, benar dan salah.

2. belajar membuat hubungan emosional yang makin matang dengan lingkungan sosial baik. dirumah maupun diluar.

- tugas perkembangan periode anak akhir

1. makin mengembangkan keterampilan motorik seperti otot halus dan otot kasar.

2. mengembangkan konsep tentang lingkungan sekitar.

3. tingkah laku moral dan menerima nilai lingkungan.

4. bekerjasama dengan teman sebayanya.

5. memainkan peran sesuai dengan jenis kelaminnya.

6. mengendalikan reaksi-reaksi emosionalnya sesuai dengan harapan lingkungan sosial.

7. belajar menjadi individu yang berdiri sendiri. jika anak mengalami gangguan secara psikologisnya dan mengakibatkan tumbuh kembang anak menjadi tidak optimal, maka anak pun tidak akan mampu menjalankan tugas-tugas perkembangannya sesuai dengan apa yang telah dikemukakan oleh Hurlock.

Seharusnya anak mendapatkan penjagaan dan perlindungan, karena anak juga memiliki hakhak yang harus dihormati keberadaannya. Perbuatan pelecehan seksual merupakan salah satu bentuk pekerjaan yang tidak dapat ditolerir keberadaannya dan merupakan pelanggaran terhadap hak asasi manusia, karena bagaimana pun anak juga mempunyai hak-hak yang harus dihormati keberadaannya dan harus dilindungi. adapun faktor-faktor penyebab terjadinya pelecehan seksual ditinjau dari sudut kriminologi yaitu, karena faktor lingkungan keluarga, faktor ekonomi keluarga yang tidak mampu, faktor lingkungan pergaulan dan faktor teknologi. Semua faktor tersebut lah yang menyebabkan anak lebih mudah menjadi korban eksploitasi secara seksual yang dilakukan baik oleh keluarga, teman, ataupun oleh oknum yang tidak bertanggungjawab yang memanfaatkan anak tersebut untuk mendapatkan yang ia inginkan.

\section{Penutup}

Masih banyaknya kasus yang melibatkan anak di Indonesia dan salah satunya adalah kasus pelecehan seksual.Hal ini disebabkan oleh banyak faktor, diantaranya faktor lingkungan, teknologi, dan kurangnya pengawasan dari berbagai pihak. Anak yang mengalami pelecehan seksual akan mengalami gangguan secara psikologis maupun fisik. Di Indonesia sendiri kasus pelecehan seksual pada anak masih kurang terperhatikan oleh komnas perlindungan anak, padahal jika dilihat banyak sekali kasus pelecahan pada anak di Indonesia yang membutuhkan perhatian lebih dan harus segera ditindak lanjuti.

Peran orangtua sangat berpengaruh dan sangat dibutuhkan untuk menjaga anak agar terhindar dari kejahatan tersebut.Selain itu, jika anak sudah menjadi korban, orangtua dan keluarga harus selalu mendampingi dan memberikan support kepada anak agar anak merasa dicinta, berharga dan dapat mengembalikan kepercayaan dirinya kembali.Jika anak sudah mulai masuk ke lingkungan baru yaitu sekolah, pihak sekolah harus memberikan perlindungan, kenyamanan, dan keamanan yang baik agar tidak terjadi kejahatan seksual seperti yang terjadi di sekolah Jakarta international school (JIS).

Karena pada masa ini anak sedang mencari jati dirinya dan mengeksplor dirinya, maka orangtua dan pihak-pihak yang terkait seperti sekolah dsb, harus saling berperan penting untuk 
mambantu anak dalam proses mencari jati dirinya. Selain itu, kinerja komnas perlindungan anak harus ditingkatkan agar kasus pelecehan seksual pada anak dapat ditindak lanjuti guna tumbuh kembang anak yang lebih baik.

\section{DAFTAR PUSTAKA}

Hurlock, Elisabeth. 1980, Psikologi Perkembangan .Jakarta : Erlangga. Winarno Budi, 2002, Isu-Isu Global Kontemporer, PT. Buku Seru, Yogyakarta Undang-undang Republik Indonesia No. 23 Tahun 2002 tentang perlindungan anak Undang-undang No. 4 (1979) Tentang Kesejahteraan Anak

\section{Jurnal/Artikel}

Paramnastri, Ira. 2010, Jurnal Psikologi Early Prevention Toward Sexual Abuse on Children. Hornor, Gail. 2010, Child Sexual Abuse: Consequences and Implication. http://jurnal.untan.ac.id/index.php/jmfh/article/view/1821

\section{Sumber Lain}

Undang-undang No. 23 Tahun 2005 Tentang Perlindungan Anak http://posyandu.org/perlindungan-dalam-keluarga/perlindungan-anak/300-ketika-anak-mengalamipelecehan-seksual.html

www.bbc.co.uk/Indonesia/berita_Indonesia/2014/08/140807_kasus_jis 